\title{
KUALITAS NUTRISI SILASE LIMBAH PISANG (BATANG DAN BONGGOL) DAN LEVEL MOLASES YANG BERBEDA SEBAGAI PAKAN ALTERNATIF TERNAK RUMINANSIA
}

\author{
I. SUTOWO, T. ADELINA DAN D. FEBRINA \\ Fakultas Pertanian dan Peternakan UIN SUSKA Riau \\ Jln. H. R Subrantas KM 15 Simpang Baru Panam-Pekanbaru \\ Email : sutowoibnu21@yahoo.com
}

\begin{abstract}
Stem and stump of bananas have potential to be used as an alternative for ruminant feed. However, one of the problem is its rapidly decomposing which affect high of water content. The alternative way to solve this matter by using silage. The aim of this study was to determine the nutritional quality of banana waste silage (stems and stump) with the addition of molasses with different levels. The experimental design was a Completely Randomized Design in factorial $3 \times 3$ with two replications. The first factor (A) was the composition of the substrate, A1: stump 100\% + stem 0\%, A2: stump 50\% + stem 50\%, and A3: stump $0 \%+$ stem $100 \%$, while the second factor (B) was the levels of molasses $(0 ; 2.5 ;$ and $5 \%)$. The parameters measured were dry matter, crude protein, crude fiber, extract ether, ash and BETN. The results showed that the composition of the substrate has significant effect $(P<0.05)$ increased content of dry matter, crude protein, crude fiber, BETN, but did not significant $(P>0.05)$ on extract ether and ash content. There was an interaction $(P<0.05)$ between the substrate composition and the addition of molasses on the content of the ash. The best composition for increasing the nutrient content was stump $100 \%+$ stemps $0 \%$. It is conclude that the compostion of stump and stemps may affect the nutrient quality of silage.
\end{abstract}

Keywords : by product, fermentation, crude protein, crude fiber

\section{PENDAHULUAN}

Pakan berfungsi untuk memenuhi kebutuhan ternak baik untuk hidup pokok, pertumbuhan, produksi dan reproduksi. Tiga faktor penting dalam penyediaan hijauan bagi ternak ruminansia adalah kesediaan pakan, kandungan gizi serta kesinambungan sepanjang tahun. Ketersediaan hijauan umumnya berfluktuasi mengikuti pola musim, pada musim penghujan hijauan melimpah sebaliknya terbatas pada musim kemarau (Lado, 2007).

Silase merupakan pengawetan hijauan secara basah, bertujuan untuk mempertahan kan kualitas hijauan serta mengatasi kekurangan pakan di musim kemarau. Limbah pertanian dan perkebunan dapat dimanfaatkan dalam pembuatan silase salah satunya adalah limbah pisang. Wina (2001) menyatakan total produksi batang pisang dalam berat segar mencapai 100 kali lipat dari produksi buah pisangnya dan total produksi daun pisang dapat mencapai 30 kali lipat dari produksi buah pisang.
Menurut Direktorat Pengembangan Potensi Daerah (DPPD, 2012) data produksi pisang di Provinsi Riau tahun 2011 adalah 26.497 ton/tahun, maka diasumsikan jumlah limbah batang dan bonggol pisang mencapai 2.649.700 ton/tahun. Berdasarkan hasil analisis Laboratorium Ilmu Nutrisi dan Kimia Fakultas Pertanian dan Peternakan UIN Suska Riau tahun 2015 kandungan gizi batang pisang adalah bahan kering 8,00\%; abu 19,50\%, protein kasar 1,01\%; serat kasar 19,50\%; lemak kasar $0,75 \%$; BETN 59,24\%, serta kandungan gizi bonggol pisang adalah bahan kering $17,46 \%$; abu 16,00\%; protein kasar 0,96\%; serat kasar 14,50\%; lemak kasar 0,75\% dan BETN $67,79 \%$.

Hernaman dkk. (2005) menyatakan molases dapat digunakan sebagai bahan pengawet dalam pembuatan silase. Molases adalah cairan kental dari limbah pemurnian gula dan merupakan sisa nira yang telah mengalami proses kristalisasi, mengandung 50-60\% gula, sejumlah asam amino dan mineral (Mubyarto \& Daryanti, 1991). Mochtar dan Tedjowahjono 
menyatakan molases dapat ditambahkan sebagai bahan pengawet dalam pembuatan silase sebanyak $1-4 \%$ dari berat hijauan. Penelitian ini bertujuan untuk mengetahui pengaruh komposisi substrat (batang dan bonggol pisang) serta level molases yang berbeda terhadap kualitas nutrisi silase limbah pisang.

\section{MATERI DAN METODE}

\section{Bahan dan Alat}

Bahan pembuatan silase adalah batang dan bonggol pisang kepok yang sudah tidak produktif yang buahnya telah dipanen (limbah) serta molases. Aquades, $\mathrm{HCl}$, $\mathrm{K}_{3} \mathrm{SO}_{4}, \mathrm{MgSO}_{4}, \mathrm{NaOH}, \mathrm{H}_{3} \mathrm{BO}_{4}$, eter, benzene, $\mathrm{CCl}_{4}$ digunakan sebagai untuk analisis kandungan gizi.

Peralatan yang digunakan adalah kantong plastik, timbangan, baskom, sendok pengaduk, cangkul, parang, kamera, pemanas, Kjeltec, soxtec, fibertec, kertas saring, tanur listrik, crucible dan alat destilasi.

\section{Metode Penelitian}

Penelitian menggunakan Rancangan Acak Lengkap (RAL) pola faktorial $3 \times 2$ masing-masing dengan 2 ulangan.

Faktor A adalah komposisi substrat $\mathrm{A} 1=100 \%$ bonggol $+\quad 0 \%$ batang $\mathrm{A} 2=50 \%$ bonggol $+50 \%$ batang $\mathrm{A} 3=0 \%$ bonggol $+100 \%$ batang

Faktor B adalah level molases $\mathrm{B} 1=0 \%$
B2 $=2,5 \%$
B3 $=5 \%$

Parameter yang diukur adalah kandungan bahan kering (BK), protein kasar (PK), serat kasar (SK), lemak kasar (LK), abu dan bahan ekstrak tanpa nitrogen (BETN).

\section{HASIL DAN PEMBAHASAN}

\section{Kandungan Bahan Kering Silase Batang dan Bonggol Pisang}

Kandungan bahan kering (BK) silase batang dan bonggol pisang dapat dilihat pada Tabel 1.

Tabel 1. Kandungan bahan kering silase batang dan bonggol pisang (\%)

\begin{tabular}{lrrrr}
\hline \multirow{2}{*}{ Komposisi Substrat (A) } & \multicolumn{3}{c}{ Penambahan Molases (B) } & \multirow{2}{*}{ Rataan } \\
\cline { 2 - 4 } A1 (Bo 100\%+ Ba $0 \%)$ & B1(0\%) & B2(2,5\%) & B3(5\%) & \\
A2 (Bo 50\% + Ba 50\%) & $3,66 \pm 0,48$ & $2,33 \pm 0,00$ & $4,17 \pm 2,60$ & $3,39^{\mathrm{a}}$ \\
A3 (Bo 0\% + Ba 100\%) & $8,49 \pm 3,55$ & $4,82 \pm 0,73$ & $4,99 \pm 1,90$ & $6,10^{\mathrm{c}}$ \\
\hline Rataan & $4,76 \pm 1,17$ & $3,99 \pm 1,41$ & $7,00 \pm 2,59$ & $5,25^{\mathrm{b}}$ \\
\hline
\end{tabular}

Ket : $\mathrm{Ba}=$ Batang, $\mathrm{Bo}=$ Bonggol, $\mathrm{M}=$ Molases,

Superskrip berbeda pada kolom yang sama menunjukkan pengaruh yang berbeda nyata $(\mathrm{P}<0,05)$

Hasil analisis ragam menunjukkan komposisi substrat yang berbeda mempengaruhi $(\mathrm{P}<0,05)$ kandungan $\mathrm{BK}$ silase batang dan bonggol pisang. Penambahan molases sampai $5 \%$ tidak mempengaruhi $(\mathrm{P}>0,05)$ kandungan $\mathrm{BK}$ silase batang dan bonggol pisang dan tidak terdapat interaksi $(\mathrm{P}>0,05)$ antara penambahan molases dan komposisi substrat terhadap kandungan BK silase batang dan bonggol pisang.
Tabel 1 memperlihatkan kandungan BK terendah terdapat pada perlakuan A1 $(3,39 \%)$ dan tertinggi pada perlakuan A2 $(6,10 \%)$. Meningkatnya kandungan BK pada perlakuan A2 $(50 \% \mathrm{Ba}+50 \% \mathrm{Bo})$ dibandingkan A1 dan A3 diduga dipengaruhi oleh komposisi substrat, hal ini disebabkan karbohidrat yang terkandung di dalam batang dan bonggol pisang (pati dan selulosa) merupakan sumber energi yang mudah dimanfaatkan oleh bakteri asam laktat untuk 
memproduksi asam laktat dalam proses ensilase. Selama proses fermentasi akan terjadi perombakan bahan kimia yang menghasilkan gas-gas yang menghilang dan pemecahan zat-zat makanan yang terlarut dan mudah dicerna. Sesuai pendapat Fardiaz (1989) mikroorganisme menggunakan karbohidrat sebagai energi setelah dipecah menjadi glukosa selanjutnya dihasilkan energi, air dan karbondioksida.

Perlakuan A3 (0\% Ba $+100 \%$ Bo) mengalami penurunan kandungan $\mathrm{BK}$ dibandingkan perlakuan A2 $(50 \% \mathrm{Ba}+$ $50 \%$ Bo) hal ini diduga bonggol pisang memiliki kadar air yang tinggi sekitar $70 \%-80 \%$, pada saat fase anaerob berlangsung bonggol pisang akan mengeluarkan air, panas dan $\mathrm{CO}_{2}$, yang menurunkan kadar BK. Sesuai pendapat Surono et al. (2006) peningkatan kandungan air pada saat ensilase menyebabkan penurunan kandungan BK sehingga meningkatkan kehilangan BK, semakin tinggi air yang dihasilkan maka penurunan BK semakin tinggi.

Penambahan molases tidak mempengaruhi $(\mathrm{P}>0,05)$ kandungan $\mathrm{BK}$ silase batang dan bonggol pisang. Hal ini diduga penambahan molases sampai $5 \%$ menyebabkan energi berupa karbohidrat yang diperoleh BAL dari molases masih relatif sama dalam mengubah kandungan BK silase batang dan bonggol pisang. Kandungan BK silase batang dan bonggol pisang pada penelitian ini berkisar 2,33-8,49\%, nilai ini lebih rendah dari silase batang pisang dengan penambahan beberapa akselerator seperti dedak padi dan tepung gaplek dimana BK silase yang didapat adalah 22,80\% (Santi et al., 2011).

\section{Kandungan Protein Kasar Silase Batang dan Bonggol Pisang}

Kandungan protein kasar (PK) silase batang dan bonggol pisang dilihat pada Tabel 2.

Tabel 2. Kandungan protein kasar silase batang dan bonggol pisang (\%)

\begin{tabular}{lrrrr}
\hline \multirow{2}{*}{ Komposisi Substrat (A) } & \multicolumn{2}{c}{ Penambahan Molases \% (B) } & \multirow{2}{*}{ Rataan } \\
\cline { 2 - 4 } & B1(0\%) & B2(2,5\%) & B3(5\%) & \\
\hline A1 (Bo 100\% + Ba $0 \%)$ & $4,91 \pm 0,37$ & $4,81 \pm 0,68$ & $5,16 \pm 0,44$ & $4,96^{\mathrm{b}}$ \\
A2 (Bo 50\%+ Ba 50\%) & $4,03 \pm 0,03$ & $3,77 \pm 0,35$ & $4,25 \pm 0,06$ & $4,00^{\mathrm{a}}$ \\
A3 (Bo 0\%+ Ba 100\%) & $7,67 \pm 0,32$ & $6,53 \pm 0,57$ & $7,05 \pm 0,57$ & $7,08^{\mathrm{c}}$ \\
\hline Rataan & 5,53 & 5,03 & 5,48 & \\
\hline
\end{tabular}

Ket : $\mathrm{Ba}=$ Batang, $\mathrm{Bo}=$ bonggol, $\mathrm{M}=$ Molases,

Superskrip berbeda pada kolom yang sama menunjukkan pengaruh berbeda nyata $(P<0,05)$

Hasil analisis ragam memperlihatkan komposisi substrat mempengaruhi $(\mathrm{P}<0,05)$ kandungan $\mathrm{PK}$ silase batang dan bonggol pisang. Penambahan molases $2,5-5 \%$ tidak mempengaruhi $(\mathrm{P}>0,05)$ kandungan PK silase batang dan bonggol pisang serta tidak terdapat interaksi $(\mathrm{P}>0,05)$ antara komposisi substrat dan penambahan molases terhadap kandungan PK.

Perubahan komposisi substrat mempengaruhi kandungan PK silase dimana $\mathrm{PK}$ terendah terdapat pada perlakuan A2 (50\% Ba $+50 \%$ Bo) yaitu $4,00 \%$ dan kandungan PK tertinggi terdapat pada perlakuan A3 $(0 \% \mathrm{Ba}+100 \%$ Bo) yaitu $7,08 \%$. Terjadi penurunan kandungan PK pada perlakuan A1 (100\% $\mathrm{Ba}+0 \%$ Bo) dibandingkan perlakuan A2 $(50 \% \mathrm{Ba}+50 \mathrm{Bo})$ diduga kondisi anaerob yang lambat tercapai pada perlakuan A2 sehingga bakteri proteolitik belum berkembang maksimal untuk menghasilkan enzim protease. Perlakuan A3 mengalami peningkatan PK dibandingkan perlakuan A2, diduga produksi enzim protease sudah maksimal sehingga menghasilkan PK tertingggi yaitu 7,08\%. Perlakuan A3 dengan kandungan $100 \%$ batang pisang diduga merupakan media yang cocok untuk 
pertumbuhan BAL dibandingkan substrat pada perlakuan lain. Perlakuan A3 (100\% batang) mengandung karbohidrat berupa selulosa 32,24\%, pada perlakuan A1 dan A2 kandungan selulosanya lebih rendah dibandingkan perlakuan A3 yaitu 15,10\% dan 20,61\%. Karbohidrat merupakan sumber energi yang mudah dimanfaatkan oleh bakteri asam laktat untuk memproduksi asam laktat sehingga perlakuan A3 (100\% batang) merupakan media atau substrat yang paling cocok untuk mendukung pertumbuhan bakteri (BAL). Santi et al. (2011) menyatakan bakteri asam laktat mempunyai kemampuan untuk memfermentasi gula menjadi asam laktat. Kondisi ini mempengaruhi kandungan PK karena tubuh bakteri mengandung lebih kurang $80 \%$ protein. Semakin banyak jumlah bakteri maka akan semakin banyak PK yang terdapat pada substrat. Sandi et al. (2010) menyatakan laju kecepatan penguraian protein (proteolisis), sangat tergantung pada laju penurunan $\mathrm{pH}$, nilai $\mathrm{pH}$ yang turun pada awal ensilase sangat bermanfaat untuk mencegah perombakan protein. Kandungan PK pada penelitian ini berkisar 4,00-7,08\%, nilai ini lebih rendah dari silase batang pisang campuran umbi singkong dan biji jagung dimana PK silase yang didapat adalah 12,17\% (Dhalika et al., 2011).

\section{Kandungan Serat Kasar Silase Batang dan Bonggol Pisang}

Kandungan serat kasar (SK) silase batang dan bonggol pisang dilihat pada Tabel 3 .

Tabel 3. Kandungan serat kasar silase batang dan bonggol pisang (\%)

\begin{tabular}{lrrrrr}
\hline \multirow{2}{*}{ Komposisi Substrat (A) } & \multicolumn{3}{c}{ Penambahan Molases (B) } & \multirow{2}{*}{ Rataan } \\
\cline { 2 - 5 } & B1(0\%) & B2(2,5\%) & B3(5\%) & \\
\hline A1 (Bo 100\% + Ba $0 \%)$ & $16,50 \pm 2,12$ & $16,50 \pm 2,12$ & $17,50 \pm 2,12$ & $16,83^{\mathrm{a}}$ \\
A2 (Bo 50\% + Ba 50\%) & $26,24 \pm 0,70$ & $25,37 \pm 0,52$ & $25,38 \pm 0,52$ & $25,66^{\mathrm{b}}$ \\
A3 (Bo 0\% + Ba 100\%) & $29,50 \pm 0,71$ & $28,00 \pm 1,41$ & $25,50 \pm 2,12$ & $27,67 \mathrm{c}$ \\
\hline Rataan & 24,08 & 23,29 & 22,79 & \\
\hline
\end{tabular}

Ket : $\mathrm{Ba}=$ Batang, $\mathrm{Bo}=$ bonggol, $\mathrm{M}=$ Molases

Superskrip berbeda pada kolom yang sama menunjukkan pengaruh berbeda nyata $(P<0,05)$

Hasil analisis ragam menunjukkan komposisi substrat yang berbeda mempengaruhi $(\mathrm{P}<0,05)$ kandungan SK silase batang dan bonggol pisang. Penambahan molases sampai $5 \%$ tidak mempengaruhi $(\mathrm{P}>0,05)$ kandungan SK silase batang dan bonggol pisang dan tidak terdapat interaksi $(\mathrm{P}>0,05)$ antara penambahan molases dan komposisi substrat terhadap kandungan SK silase batang dan bonggol pisang.

Tabel 3 memperlihatkan komposisi substrat yang berbeda secara nyata $(\mathrm{P}<0,05)$ meningkatkan SK silase batang dan bonggol pisang. Peningkatan kandungan SK diduga dipengaruhi oleh kandungan bahan sebelum proses silase yaitu kandungan SK batang adalah 19,5\% dan bonggol 14,50\%. Hasil penelitian memperlihatkan semakin meningkat persentase batang pisang maka akan meningkatkan kandungan SK silase, yaitu meningkat dari 16,83 menjadi $27,67 \%$. Dhalika et al. (2011) menyatakan fraksi serat batang pisang mengalami degradasi menjadi komponen karbohidrat yang lebih sederhana pada proses ensilase akibat pertumbuhan mikroba pembentuk asam laktat. Santi et al. (2011) menjelaskan kadar SK yang rendah dapat disebabkan oleh adanya panas fermentasi dan $\mathrm{pH}$ rendah dari asam organik yang menyebabkan komponen-komponen karbohidrat dari SK mengalami hidrolisis atau penguraian sehingga banyak bagian yang terlarut. Kandungan SK silase batang dan bonggol pisang berkisar 16,50-29,50\%, hasil ini lebih tinggi dari silase batang pisang, campuran umbi singkong dan biji jagung 
dimana SK silase 18,80-19,71\% (Dhalika et al., 2011).

\section{Kandungan Lemak Kasar Silase Batang dan Bonggol Pisang}

Kandungan lemak kasar (LK) silase batang dan bonggol pisang dilihat pada Tabel 4.

Tabel 4. Kandungan lemak kasar silase batang dan bonggol pisang (\%)

\begin{tabular}{lcccc}
\hline \multirow{2}{*}{ Komposisi Bahan (A) } & \multicolumn{3}{c}{ Penambahan Molases (B) } & \multirow{2}{*}{ Rataan } \\
\cline { 2 - 4 } & $\mathrm{B} 1(0 \%)$ & $\mathrm{B} 2(2,5 \%)$ & $\mathrm{B} 3(5 \%)$ & \\
\hline A1 (Bo 100\%+ Ba 0\%) & $0,75 \pm 0,35$ & $0,74 \pm 0,35$ & $0,74 \pm 0,34$ & 0,74 \\
A2 (Bo 50\%+ Ba 50\%) & $0,50 \pm 0,00$ & $0,50 \pm 0,00$ & $0,50 \pm 0,00$ & 0,50 \\
A3 (Bo 0\%+ Ba 100\%) & $0,50 \pm 0,00$ & $0,50 \pm 0,00$ & $0,75 \pm 0,35$ & 0,58 \\
\hline Rataan & 0,83 & 0,58 & 0,66 & \\
\hline
\end{tabular}

Keterangan $: \mathrm{Ba}=$ Batang, $\mathrm{Bo}=$ bonggol, $\mathrm{M}=$ Molases

Hasil analisis ragam menunjukkan komposisi substrat dan penambahan molases yang berbeda tidak berpengaruh $(\mathrm{P}>0,05)$ terhadap kandungan LK silase batang dan bonggol pisang, tidak ada interaksi $(\mathrm{P}>0,05)$ antara komposisi substrat dan penambahan molases terhadap kandungan LK silase batang dan bonggol pisang.

Tidak terjadinya perubahan kandungan LK pada silase batang dan bonggol pisang diduga selama proses ensilase tidak banyak terjadi pemecahan lemak menjadi asam lemak. Pada proses silase bakteri yang berkembang adalah BAL yang menghasilkan asam laktat dan bukan menghasilkan enzim lipase. Chen dan Weinberg (2008) menyatakan fermentasi silase yang baik didominasi oleh BAL dan menghasilkan konsentrasi asam organik yang didominasi oleh asam laktat.

Kandungan LK silase batang dan bonggol pisang dalam penelitian ini hampir sama dengan kandungan LK batang dan bonggol pisang segar yaitu kandungan LK batang dan bonggol perlakuan A1 dan A3 sebelum proses silase adalah $0,75 \%$ dan kandungan batang dan batang dan bonggol setelah silase berkisar 0,50-0,74\%. Apabila kandungan LK setelah fermentasi tidak berbeda dengan kandungan lemak kasar sebelum fermentasi, artinya proses silase yang terjadi dapat mempertahankan kandungan lemak kasar batang dan pisang dari proses perusakan zat makanan, khususnya lemak kasar (Dhalika et al., (2011). Tidak terjadinya perubahan kandungan LK pada silase diduga dipengaruhi BAL yang tidak terlalu banyak membutuhkan lemak untuk pertumbuhan dan perkembangannya sehingga tercermin pada kandungan LK yang relatif sama pada semua perlakuan.

\section{Kandungan Abu Silase Batang dan Bonggol Pisang}

Kandungan abu silase batang dan bonggol pisang dilihat pada Tabel 5.

Tabel 5. Kandungan abu silase batang dan bonggol pisang (\%)

\begin{tabular}{|c|c|c|c|c|}
\hline \multirow{2}{*}{ Komposisi substrat (A) } & \multicolumn{3}{|c|}{ Penambahan Molases (B) } & \multirow{2}{*}{ Rataan } \\
\hline & $\mathrm{B} 1(0 \%)$ & B2(2,5\%) & $\mathrm{B} 3(5 \%)$ & \\
\hline A1 (Bo $100 \%+$ Ba $0 \%)$ & $11,82^{\mathrm{cA}} \pm 0,73$ & $11,67^{\mathrm{bA}} \pm 1,41$ & $11,34^{\mathrm{aA}} \pm 0,94$ & 11,61 \\
\hline $\mathrm{A} 2(\mathrm{Bo} 50 \%+\mathrm{Ba} 50 \%)$ & $13,98^{\mathrm{aB}} \pm 0,44$ & $14,46^{\mathrm{bB}} \pm 0,30$ & $14,64^{\mathrm{bB}} \pm 0,44$ & 14,36 \\
\hline A3 (Bo $0 \%+$ Ba $100 \%)$ & $18,27 \mathrm{aC} \pm 0,47$ & $18,94 \mathrm{cC} \pm 0,00$ & $16,34 \mathrm{bC} \pm 0,47$ & 17,85 \\
\hline Rataan & 14,69 & 15,02 & 14,10 & \\
\hline
\end{tabular}


Hasil analisis ragam menunjukkan komposisi substrat dan penambahan molases yang berbeda tidak berpengaruh $(\mathrm{P}>0,05)$ terhadap kandungan abu silase batang dan bonggol pisang, terdapat interaksi $(\mathrm{P}<0,05)$ antara komposisi substrat dan penambahan molases terhadap kandungan abu silase batang dan bonggol pisang.

Perubahan kandungan abu diduga dipengaruhi kandungan mineral yang terdapat pada substrat. Abu merupakan komponen anorganik yang tersusun atas mineral seperti $\mathrm{Ca}, \mathrm{P}$ dan lainya. Pada proses ensilase BAL membutuhkan mineral untuk mendukung pertumbuhan dan perkembangannya. Wina (2001) menyatakan kandungan abu yang tinggi pada batang pisang mencerminkan kandungan mineral yang tinggi pada bagian tanaman pisang. Kandungan abu pada penelitian ini berkisar 11,34-18,94\%, hasil ini lebih rendah dari kadar abu silase batang pisang dengan penambahan beberapa akselerator seperti dedak padi dan tepung gaplek yaitu 25,12\% (Santi et al., 2011).

\section{Kandungan Bahan Ekstrak Tanpa Nitrogen Silase Batang dan Bonggol Pisang}

Kandungan BETN silase batang dan bonggol pisang dilihat pada Tabel 6 .

Tabel 6. Kandungan BETN Silase Batang dan Bonggol Pisang (\%)

\begin{tabular}{lccrc}
\hline \multirow{2}{*}{ Komposoisi Substrat (A) } & \multicolumn{2}{c}{ Penambahan Molases (B) } & \multirow{2}{*}{ Rataan } \\
\cline { 2 - 4 } & B1(0\%) & B2(2,5\%) & B3(5\%) & \\
\hline A1 (Bo 100\%+ Ba 0\%) & $66,04 \pm 3,58$ & $66,31 \pm 3,84$ & $65,27 \pm 3,15$ & $65,87 \mathrm{c}$ \\
A2 (Bo 50\%+ Ba 50\%) & $55,29 \pm 0,23$ & $55,94 \pm 0,12$ & $54,75 \pm 1,25$ & $55,32^{\mathrm{b}}$ \\
A3 (Bo 0\%+ Ba 100\%) & $43,82 \pm 0,43$ & $45,79 \pm 2,34$ & $50,12 \pm 3,15$ & $46,57^{\mathrm{a}}$ \\
\hline Rataan & 55,05 & 56,01 & 56,71 & \\
\hline
\end{tabular}

Ket $: \mathrm{Ba}=$ Batang, $\mathrm{Bo}=$ bonggol, $\mathrm{M}=$ Molases

Superskrip berbeda pada kolom yang sama menunjukkan pengaruh berbeda nyata $(P<0,05)$

Hasil analisis ragam menunjukkan komposisi substrat yang berbeda mempengaruhi $(\mathrm{P}<0,05)$ kandungan BETN silase batang dan bonggol pisang. Penambahan molases tidak mempengaruhi $(\mathrm{P}>0,05)$ kandungan $\mathrm{BETN}$ silase batang dan bonggol pisang dan tidak terdapat interaksi $(\mathrm{P}>0,05)$ antara komposisi substrat dan penambahan molases terhadap kandungan BETN silase batang dan bonggol pisang.

Tabel 6 memperlihatkan komposisi substrat yang berbeda berpengaruh nyata $(\mathrm{P}<0,05)$ menurunkan kandungan BETN silase batang dan bonggol pisang. Penurunan kandungan BETN pada silase batang dan bonggol pisang dipengaruhi oleh perubahan nutrisi yang dikandung pada silase tersebut. Kandungan PK dan SK memperlihatkan peningkatan seiring dengan perubahan komposisi substrat. Kandungan PK sebelum silase yaitu 1,01-0,96\% meningkat menjadi 7,08-4,96\% setelah silase dan kandungan SK sebelum silase adalah $19,50-14,50 \%$ setelah proses silase mengalami perubahan yaitu $27,67-16,83 \%$. Nilai tersebut berpengaruh terhadap kandungan BETN.

Tilman et al. (1990) menyatakan BETN terdiri atas monosakarida, disakarida, trisakarida dan polisakarida terutama pati yang mudah larut dalam larutan asam dan basa dalam analisis serat kasar yang memiliki daya cerna yang tinggi. Hal ini memudahkan bakteri asam laktat menggunakan karbohidrat mudah larut untuk menghasilkan asam laktat. Kandungan BETN silase batang dan bonggol pisang dalam penelitian ini berkisar 43,82-66,31\%, nilai ini lebih rendah dari BETN silase batang pisang campuran umbi singkong dan biji jagung yaitu 47,21\% (Dhalika et al., 2011). 


\section{KESIMPULAN}

1. Penambahan molases sampai $5 \%$ tidak dapat mempengaruhi kandungan lemak kasar dan BETN.

2. Komposisi substrat yang berbeda meningkatkan kandungan bahan kering, protein kasar dan serat kasar

3. Interaksi antara substrat dan molases mempengaruhi kandungan abu.

4. Perlakuan dengan komposisi substrat $100 \%$ bonggol dan $0 \%$ batang memberikan hasil terbaik karena meningkatkan kandungan bahan kering, protein kasar, lemak kasar, abu dan BETN.

\section{DAFTAR PUSTAKA}

Chen, Y \& Z. G. Weinberg. 2008. Changes during aerobic exposure of wheat silage. Anim. Feed Sci. Technology. 154:76-82.

Dhalika, T. Mansyur, dan A. R, Tarmidi. 2011. Nilai Nutrisi Batang Pisang dari Produk Bioproses (Ensilage) sebagai Ransum Lengkap. Jurnal Ilmu Ternak.11(1):17-23.

Direktorat Pengembangan Potensi Daerah (DPPD). 2012. Prospek dan Arah Pengembangan Agribisnis Pisang. Direktorat Pengembangan Potensi Daerah Nasional.

Fardiaz, S. 1989. Mikrobiologi Pangan Edisi 1. Gramedia Pustaka Utama. Jakarta.

Hernaman, I. Hidayat, R. dan Mansyur. 2005. Pengaruh Penggunaan Molases dalam Pembuatan Silase Campuran Ampas Tahu dan Pucuk Tebu Kering terhadap Nilai pH dan Zat-Zat Makanannya. Jurnal Ilmu Ternak. 5(2):94-99.

Lado. 2007. Evaluasi Kualitas Silase Rumput Sudan (Sorghon Sudanese) pada Penambahan Berbagai Macam Aditif Karbohidrat Mudah Larut. Tesis. Pascasarjana Program Studi Ilmu Peternakan. Universitas Gadjah Mada. Yogyakarta.
Mochtar, M. dan Tedjowahjono, S. 1985. Pemanfaatan Tetes sebagai Hasil Samping Industri Gula dalam Menunjang Perkembangan Peternakan. Dalam Seminar Pemanfaatan Pucuk Tebu Untuk Pakan Ternak. Badan Litbang Pertanian, Bogor.

Mubyarto dan Daryanti. 1991. Gula: Kajian Sosial Ekonomi. Penerbit Aditya Media. Yogyakarta.

Sandi, S. E. B. Laconi. A. Sudarman, K. G. Wiryawan dan D. Mangundjaja. 2010. Kualitas Silase Berbahan Baku Singkong yang Diberi Enzim Cairan Rumen Sapi dan Leuconostoc mesenteroides. Media Peternakan. 33(1):25-30.

Santi, R. K. D. Widyawati, W. P. S. dan Suprayogi. 2011. Kualitas dan Nilai Kecernaan In Vitro Silase Batang Pisang (Musa Paradisiaca) dengan Penambahan Beberapa Akselator. Jurnal Tropical Animal Husbandry. 1(1):15-23.

Surono, M. Soejono. dan S.P.S. Budhi. 2006. Kehilangan Bahan Kering dan Bahan Organik Silase rumput Gajah Pada Umur Potong dan Level Aditif yang Berbeda. Jurnal Tropical Animal Husbandry. 31(1): 6267.

Tilman,A, D. Hartadi, H. R. dan Reksohardiprodjo. 1990. Komposisi Pakan Untuk Indonesia. Gadjah Mada University Press. Yogyakarta.

Wina, E. 2001. Tanaman Pisang sebagai Makanan Ternak Ruminansia. Jurnal Wartazoa.11(1):20-27. 